\title{
Meta-analyses of seven GIGYF2 polymorphisms with Parkinson's disease
}

\author{
DONGJUN DAI $^{1^{*}}$, YUNLIANG WANG $^{2 *}$, XINGYU ZHOU $^{1 *}$, JIANMIN TAO $^{1}$, DANJIE JIANG $^{1}$, \\ HANLIN ZHOU ${ }^{1}$, YI JIANG ${ }^{1}$, GUANGHUI PAN ${ }^{1}$, PING RU ${ }^{1}$, HUIHUI JI ${ }^{1}$, JINFENG LI ${ }^{2}$, \\ YUZHENG ZHANG ${ }^{2}$, HONGLEI YIN ${ }^{2}$, MINGQING XU ${ }^{3}$ and SHIWEI DUAN ${ }^{1}$
}

\begin{abstract}
${ }^{1}$ Zhejiang Provincial Key Laboratory of Pathophysiology, School of Medicine, Ningbo University, Ningbo, Zhejiang 315211; ${ }^{2}$ Department of Neurology, The 148 Central Hospital of People's Liberation Army, Zibo, Shandong 255300;

${ }^{3}$ Bio-X Institutes, Key Laboratory for the Genetics of Developmental and Neuropsychiatric Disorders (Ministry of Education), Shanghai Jiao Tong University, Xuhui, Shanghai 200240, P.R. China
\end{abstract}

Received June 1, 2014; Accepted July 8, 2014

DOI: 10.3892/br.2014.324

\begin{abstract}
Parkinson's disease (PD) is the second most common neurodegenerative disorder that affects $\sim 2 \%$ of the global population aged $\geq 65$ years. Grb10-interacting GYF protein-2 (GIGYF2) can influence the development of PD through the regulation of insulin-like growth factor-1. The aim of the present meta-analysis study was to establish the contribution of GIGYF2 polymorphisms to PD. The study was conducted based on nine eligible studies consisting of 7,246 PD patients and 7,544 healthy controls. The results indicated that the GIGYF2 C.3630A $>\mathrm{G}$ polymorphism increased the risk of $\mathrm{PD}$ by $37 \%[\mathrm{P}=0.008$; odds ratio (OR), 1.37; 95\% confidence interval (CI), 1.08-1.73] and that the GIGYF2 C.167G $>$ A polymorphism was significantly associated with $\mathrm{PD}(\mathrm{P}=0.003$; OR, 3.67; 95\% CI, 1.56-8.68). The meta-analyses of the other five GIGYF2 polymorphisms (C.1378C >A, C.1554G $>$ A, C.2940A $>$ G, C.1370C $>$ A and C. $3651 \mathrm{G}>\mathrm{A}$ ) did not reveal any significant associations. The present meta-analyses of the GIGYF 2 genetic polymorphisms may provide a comprehensive overview of this PD candidate gene for future studies.
\end{abstract}

Correspondence to: Professor Shiwei Duan, Zhejiang Provincial Key Laboratory of Pathophysiology, School of Medicine, Ningbo University, 818 Fenghua Road, Ningbo, Zhejiang 315211, P.R. China E-mail: duanshiwei@nbu.edu.cn

Dr Yunliang Wang, Department of Neurology, The 148 Central Hospital of People's Liberation Army, 7 East Xinjian Road, Zibo, Shandong 255300, P.R. China

E-mail: wangyunliang81@163.com

*Contributed equally

Key words: Parkinson's disease, Grb10-interacting GYF protein-2, meta-analysis, C.3630A >G, C.167G >A

\section{Introduction}

Parkinson's disease (PD; OMIM: 168600) is the second most common neurodegenerative disorder, affecting $\sim 2 \%$ of the global population aged $\geq 65$ years $(1,2)$. The clinical features of PD consist of resting tremor, muscular rigidity, bradykinesia and postural instability (3). PD can lead to pain (4), depression $(5,6)$, visual hallucinations (6), dementia (7) and other non-motor symptoms (8-11). PD can cause damage and can even cause the human body to collapse.

The pathogenesis of PD is known to be associated with environmental and genetic factors. The environmental hypothesis of PD was popular in the 20th century (3). A number of environmental factors were found to be significantly associated with PD, including oxidative stress (12), smoking (13) and environmental toxins (14). In addition, genetic factors play an essential role in this complex disease. Twin (15) and family (16) studies have shown a higher PD susceptibility in twins and the first-degree relatives, respectively. Genome-wide linkage analysis provided evidence that the gene-by-gene interactions are important in PD susceptibility (17). A number of genetic markers have been identified for the risk of PD (18) and were shown to be potential therapeutic targets to PD $(19,20)$.

Grb10-interacting GYF protein-2 (GIGYF2) is located within the PARK11 locus, an established locus of PD (21). The Grb10 adapter protein interacts with GIGYF2, which regulates the insulin-like growth factor-1 (IGF-1), stimulating the growth of the insulin signal $(22,23)$. The IGFs affect the development of the nervous system by preventing the apoptosis of neuronal and brain-derived cells (24-26). A previous study found an association between serum IGF-1 and the progression of motor symptoms in the early stage of PD (27). In addition, IGF-1 was shown to correlate with the clinical variables and diagnosis of PD (27-29). Therefore, GIGYF2 may be a candidate factor for the risk of PD through its interaction with IGF-1.

Previously, several studies have performed an association study between the GIGYF2 polymorphisms and PD (30-43). Among them, four studies showed a positive association of the GIGYF2 polymorphisms with PD (30-33), whereas the 


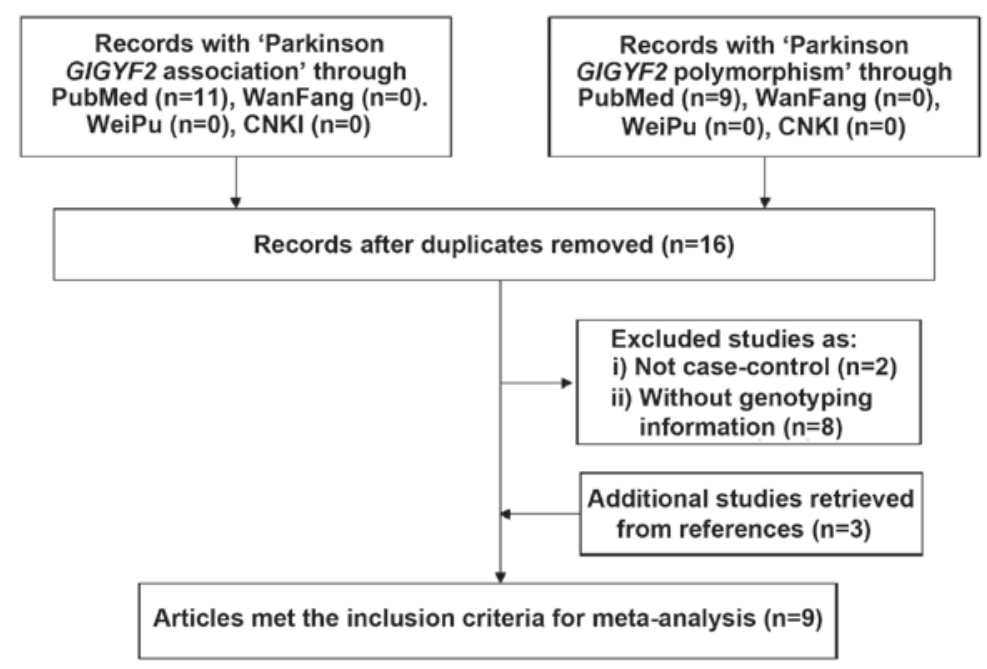

Figure 1. Flowchart of the meta-analyses selection process.

other 10 studies showed a negative association (34-43). These inconsistent results indicated that the exact role that GIGYF2 played in the pathophysiology of PD remains to be elucidated. Meta-analysis is able to enhance the reliability of the conclusion from individual studies by combining the data from various studies. To determine the genetic effect of GIGYF2 on PD, a comprehensive meta-analysis was performed among various case-control association studies with available genotypic and allelic frequencies.

\section{Materials and methods}

Data collection. Studies were selected from PubMed using the following key words: 'Parkinson GIGYF2 association' and 'Parkinson GIGYF2 polymorphism'. Eligible studies for the meta-analysis were required to meet the following criteria: i) An original case-control study with the assessment of the association between $G I G Y F 2$ and PD; ii) the study provides enough data for obtaining or calculating the odds ratios (ORs) and $95 \%$ confidence intervals (CIs) with the data of the study; iii) contains genotype distribution of each polymorphism that meet the Hardy-Weinberg equilibrium (HWE); and iv) the study is involved with polymorphisms reported by $>3$ independent studies. As shown in the previous studies (44-47), the following information was extracted or calculated from each study: Genetic locus, first author's name, year of publication, country, numbers of cases and controls, ethnicity, reported association results, power of each case-control study and the minor allele frequency (MAF) of controls.

Statistical analysis. HWE was tested by the Arlequin program (48). The power of each study was calculated by the Power and Sample Size Calculation program. Statistical heterogeneity across the studies included in the meta-analysis was assessed by Cochran's Q statistic and $\mathrm{I}^{2}$ test (49) to determine the type of analysis. In the meta-analysis, the fixed-effect model was used for the studies with minimal to moderate heterogeneity $\left(\mathrm{I}^{2}<50 \%\right)$ and the random-effect model was used for the studies with significant heterogeneity $\left(I^{2} \geq 50 \%\right)$. Funnel plots were also generated to observe the potential publication bias. The statistical analyses of meta-analyses were performed in Review Manager 5 (50).

\section{Results}

Associations between PD and GIGYF2 polymorphisms. As shown in Fig. 1, 20 studies regarding the association of GIGYF2 with PD were obtained from PubMed. There were no relevant studies found in the Chinese database WanFang, WeiPu and China National Knowledge Infrastructure. In total, four duplicates, two non-case-control and eight without genotyping information studies were removed and three studies were added that were obtained from the references. Therefore, there were nine studies selected regarding seven GIGYF2 polymorphisms, which were C.1378C $>$ A, C.167G $>$ A, C.1554G $>$ A, C.2940A $>$ G, C.1370C $>$ A, C.3630A $>$ G and C.3651G $>A$ (Table I). In particular, there were six studies with 2,281 cases and 1,815 controls for C.1378C $>$ A, five with 5,519 cases and 6,316 controls for $\mathrm{C} .167 \mathrm{G}>\mathrm{A}$, four with 1,611 cases and 1,460 controls for C.1554G $>$ A, four with 1,611 cases and 1,460 controls for C.2940A $>$ G, three with 3,876 cases and 4,688 controls for $C .1370 \mathrm{C}>\mathrm{A}$, three with 1,311 cases and 1,260 controls for C.3630A $>\mathrm{G}$ and three studies with 1,311 cases and 1,260 controls for the C.3651G>A.

A significant association was found between the C.3630A $>$ G $(\mathrm{P}=0.008$; OR, 1.37; 95\% CI, 1.08-1.73; Table II; Fig. 2) and C.167G $>A(P=0.003$; OR, 3.67; 95\% CI, 1.56-8.68; Table II; Fig. 2) polymorphisms and PD. There were no other positive results in the remaining allelic analysis $(\mathrm{P}>0.05$; Table II; Fig. 2). Low heterogeneity was found for C.1378C $>\mathrm{A}$ $\left(\mathrm{I}^{2}=0 \%\right)$, C. $167 \mathrm{G}>\mathrm{A} \quad\left(\mathrm{I}^{2}=41 \%\right), \mathrm{C} .3651 \mathrm{G}>\mathrm{A} \quad\left(\mathrm{I}^{2}=0 \%\right)$, C.1370C $>$ A $\left(I^{2}=0 \%\right), C .3630 A>G\left(I^{2}=28 \%\right)$ and C.2940A $>G$ $\left(\mathrm{I}^{2}=40 \%\right)$. By contrast, a significant statistical heterogeneity was observed in the meta-analysis of $\mathrm{C} .1554 \mathrm{G}>\mathrm{A}\left(\mathrm{I}^{2}=82 \%\right)$. There was no publication bias for all the meta-analyses (Fig. 3).

As shown in Tables I and II, the present meta-analyses showed a much stronger power than for each of the individual studies. There was sufficient power (Power $>0.8$ ) for the meta-analyses of C.2940A $>\mathrm{G}$ (Power=0.885) and C. $3651 \mathrm{G}>\mathrm{A}$ (Power $=0.824)$. By contrast, relatively lower 
Table I. Characteristics of the case-control studies in the current meta-analyses.

\begin{tabular}{|c|c|c|c|c|c|c|c|c|}
\hline First author & Year & Country & Cases/controls & Ethnicity & Results $^{\mathrm{a}}$ & Power & MAF & (Refs.) \\
\hline \multicolumn{9}{|c|}{ GIGYF2 C.1378C >A } \\
\hline Lautier & 2008 & Italy & $249 / 227$ & European & NS & 0.068 & 0.0198 & $(40)$ \\
\hline Guo & 2009 & USA & $310 / 120$ & European & NS & 0.053 & 0.0167 & (33) \\
\hline $\mathrm{Cao}$ & 2010 & China & $510 / 481$ & Asian & NS & 0.313 & 0.1455 & $(35)$ \\
\hline Guella & 2011 & Italy & $552 / 552$ & European & NS & 0.114 & 0.0281 & $(54)$ \\
\hline Wang & 2011 & China & $300 / 200$ & Asian & NS & 0.207 & 0.1975 & $(30)$ \\
\hline Meeus & 2011 & Belgium & $305 / 360$ & European & NS & 0.112 & 0.0680 & (43) \\
\hline \multicolumn{9}{|c|}{ GIGYF2 C.167G>A } \\
\hline Lautier & 2008 & Italy & $249 / 227$ & European & NS & NA & 0.0000 & $(40)$ \\
\hline Zimprich & 2009 & Austria & $699 / 1051$ & European & NS & 0.056 & 0.0005 & $(38)$ \\
\hline Bonetti & 2009 & Italy & $2928 / 3410$ & European & NS & 0.053 & 0.0001 & (41) \\
\hline Vilarino-Guell & 2009 & Norway \& USA & $1338 / 1268$ & European & $\mathrm{S}$ & NA & 0.0000 & $(42)$ \\
\hline Meeus & 2011 & Belgium & $305 / 360$ & European & NS & 0.059 & 0.0056 & (43) \\
\hline \multicolumn{9}{|c|}{ GIGYF2 C.1554G >A } \\
\hline Lautier & 2008 & Italy & $249 / 227$ & European & NS & 0.083 & 0.0352 & $(40)$ \\
\hline $\mathrm{Cao}$ & 2010 & China & $510 / 481$ & Asians & $\mathrm{S}$ & 0.254 & 0.1071 & $(35)$ \\
\hline Wang & 2011 & China & $300 / 200$ & Asian & NS & 0.197 & 0.1825 & $(30)$ \\
\hline Guella & 2011 & Italy & $552 / 552$ & European & NS & 0.147 & 0.0426 & $(54)$ \\
\hline \multicolumn{9}{|c|}{$G I G Y F 2$ C.2940A >G } \\
\hline Lautier & 2008 & Italy & $249 / 227$ & European & NS & 0.264 & 0.3194 & $(40)$ \\
\hline Cao & 2010 & China & $510 / 481$ & Asian & NS & 0.298 & 0.1351 & $(35)$ \\
\hline Wang & 2011 & China & $300 / 200$ & Asian & $\mathrm{S}$ & 0.275 & 0.3550 & (30) \\
\hline Guella & 2011 & Italy & $552 / 552$ & European & NS & 0.505 & 0.2870 & $(54)$ \\
\hline \multicolumn{9}{|c|}{ GIGYF2 C.1370C >A } \\
\hline Lautier & 2008 & Italy & $249 / 227$ & Europeans & NS & NA & 0.0000 & $(40)$ \\
\hline Zimprich & 2009 & Austria & $699 / 1051$ & European & NS & 0.059 & 0.0014 & $(38)$ \\
\hline Bonetti & 2009 & Italy & $2928 / 3410$ & European & NS & 0.053 & 0.0006 & (41) \\
\hline \multicolumn{9}{|c|}{$G I G Y F 2$ C. $3630 \mathrm{~A}>\mathrm{G}$} \\
\hline Lautier & 2008 & Italy & $249 / 227$ & European & NS & 0.070 & 0.0220 & $(40)$ \\
\hline Cao & 2010 & China & $510 / 481$ & Asian & $\mathrm{S}$ & 0.297 & 0.1341 & $(35)$ \\
\hline Guella & 2011 & Italy & $552 / 552$ & European & NS & 0.056 & 0.0027 & (54) \\
\hline \multicolumn{9}{|c|}{$G I G Y F 2$ C.3651G $>\mathrm{A}$} \\
\hline Lautier & 2008 & Italy & $249 / 227$ & European & NS & 0.223 & 0.2247 & (40) \\
\hline Cao & 2010 & China & $510 / 481$ & Asian & NS & 0.335 & 0.1611 & (35) \\
\hline Guella & 2011 & Italy & $552 / 552$ & European & NS & 0.463 & 0.2391 & (54) \\
\hline
\end{tabular}

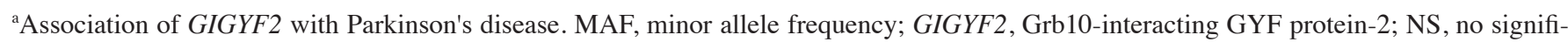
cant; NA, not applicable; S, significant.

power values were found for the meta-analyses of C.1378C $>\mathrm{A}$ (Power=0.634), C.1554G $>$ A (Power $=0.547)$, C.3630A $>\mathrm{G}$ $($ Power $=0.357)$, C.167G $>$ A $($ Power $=0.063)$ and C.1370C $>A$ (Power=0.065).

\section{Discussion}

GIGYF2 is potentially involved in the pathogenesis of PD due to the effect of IGF-1 in the insulin signaling in the central nervous system (51-53). In the present study, a meta-analyses was performed among 7,246 cases and 7,544 controls to evaluate the association between seven polymorphisms of GIGYF2 and PD.
An increased risk of PD by $37 \%$ was observed for C.3630A $>$ G. GIGYF2 C.3630A $>$ G is a key polymorphism in the previous PD studies $(35,40,54)$. Since the power of C.3630A $>\mathrm{G}$ was moderate, further studies should be conducted to confirm this positive finding. The C.3630G allele frequency was $13.4 \%$ in the Asian population, which was much higher compared to the European population (Table I), although a low heterogeneity was found for this polymorphism. In addition, meta-analysis of C.167C $>$ A from five studies $(38,40-43)$ was also shown to be significantly associated with the risk of PD. No significant association was found for the other five GIGYF2 polymorphisms, which 


\begin{tabular}{|c|c|c|c|c|c|c|}
\hline \multirow{2}{*}{$\begin{array}{l}\text { Study or Subgroup } \\
\text { C.1378C }>A\end{array}$} & \multicolumn{2}{|c|}{ Cases } & \multicolumn{2}{|c|}{$\begin{array}{l}\text { Controls } \\
\text { Events Total }\end{array}$} & Weight & Odds Ratio $95 \% \mathrm{Cl}$ \\
\hline & & & & & & \\
\hline Lautier 2008 & 9 & 498 & 9 & 454 & $3.4 \%$ & $0.91[0.36,2.31]$ \\
\hline Guo 2009 & 9 & 620 & 4 & 240 & $2.1 \%$ & $0.87[0.27,2.85]$ \\
\hline Cao 2010 & 154 & 1020 & 140 & 962 & $45.2 \%$ & $1.04[0.81,1.34]$ \\
\hline Meeus 2011 & 49 & 720 & 32 & 610 & $11.9 \%$ & $1.32[0.83,2.09]$ \\
\hline Wang 2011 & 151 & 600 & 79 & 400 & $26.2 \%$ & $1.37[1.00,1.86]$ \\
\hline Guella 2011 & 29 & 1104 & 31 & 1104 & $11.2 \%$ & $0.93[0.56,1.56]$ \\
\hline Total $(95 \% \mathrm{Cl})$ & & 4562 & & 3770 & $100.0 \%$ & $1.14[0.97,1.34]$ \\
\hline Total events & 401 & & 295 & & & \\
\hline
\end{tabular}

Heterogeneity: $\mathrm{Chi}^{2}=3.21, \mathrm{df}=5(\mathrm{P}=0.67) ; \mathrm{I}^{2}=0 \%$

Test for overall effect: $Z=1.58(P=0.11)$

\section{C. $167 \mathrm{C}>\mathrm{A}$}

Lautier 2008

Vilariño-Güell 2009

Zimprich 2009

$\begin{array}{rr}4 & 498 \\ 7 & 2676 \\ 1 & 1398 \\ 8 & 5856 \\ 2 & 610\end{array}$

$\begin{array}{llll}0 & 454 & 8.1 \% & 8.27[0.44,154.07] \\ 2008\end{array}$

Bonetti 2009

Meeus 2011

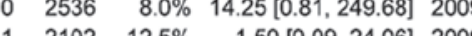

Total $(95 \% \mathrm{Cl})$

11038

$16820 \quad 14.4 \%$

$1.50[0.09,24.06] 2009$

Total events

$12632100.0 \%$

$9.33[1.17,74.60] 2009$

$0.59[0.11,3.23] 2011$

Heterogeneity: $\mathrm{Chi}^{2}=6.78$, df = $4(P=0.15) ; \mathrm{I}^{2}=41 \%$

Test for overall effect: $Z=2.97(P=0.003)$

$3.67[1.56,8.68]$

\section{C. $1554 \mathrm{G}>\mathrm{A}$}

\begin{tabular}{|c|c|c|c|c|c|}
\hline Lautier 2008 & 26 & 498 & 16 & 454 & $19.9 \%$ \\
\hline Cao 2010 & 58 & 1020 & 103 & 962 & $27.1 \%$ \\
\hline Wang 2011 & 106 & 600 & 73 & 400 & $27.2 \%$ \\
\hline Guella 2011 & 57 & 1104 & 47 & 1104 & $25.7 \%$ \\
\hline Total $(95 \% \mathrm{Cl})$ & & 3222 & & 2920 & $100.0 \%$ \\
\hline Total events & 247 & & 239 & & \\
\hline
\end{tabular}

$1.51[0.80,2.85]$

$0.50[0.36,0.70]$

$0.96[0.69,1.34]$

$1.22[0.82,1.82]$

$0.94[0.59,1.50]$
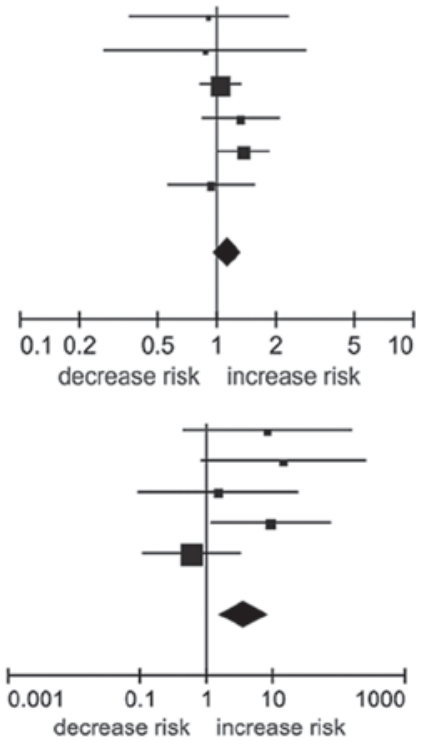

Test for overall effect: $Z=0.27(P=0.79)$

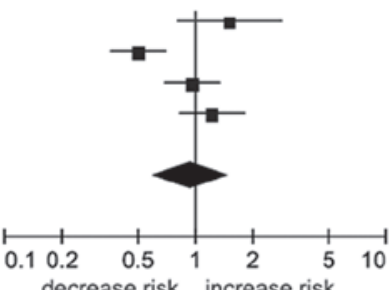

\section{C.2940A>G}

\begin{tabular}{|c|c|c|c|c|c|c|}
\hline Lautier 2008 & 140 & 498 & 145 & 454 & $20.0 \%$ & $0.83[0.63,1.10]$ \\
\hline Cao 2010 & 164 & 1020 & 130 & 962 & $20.6 \%$ & $1.23[0.96,1.57]$ \\
\hline Wang 2011 & 221 & 600 & 142 & 400 & $19.8 \%$ & $1.06[0.81,1.38]$ \\
\hline Guella 2011 & 352 & 1104 & 317 & 1104 & $39.6 \%$ & $1.16[0.97,1.39]$ \\
\hline Total $(95 \% \mathrm{Cl})$ & & 3222 & & 2920 & $100.0 \%$ & $1.09[0.97,1.22]$ \\
\hline Total events & 877 & & 734 & & & \\
\hline
\end{tabular}

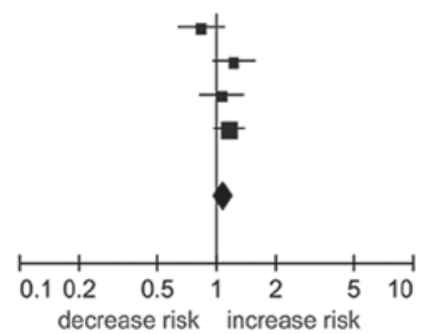

\section{C. $1370 \mathrm{C}>\mathrm{A}$}

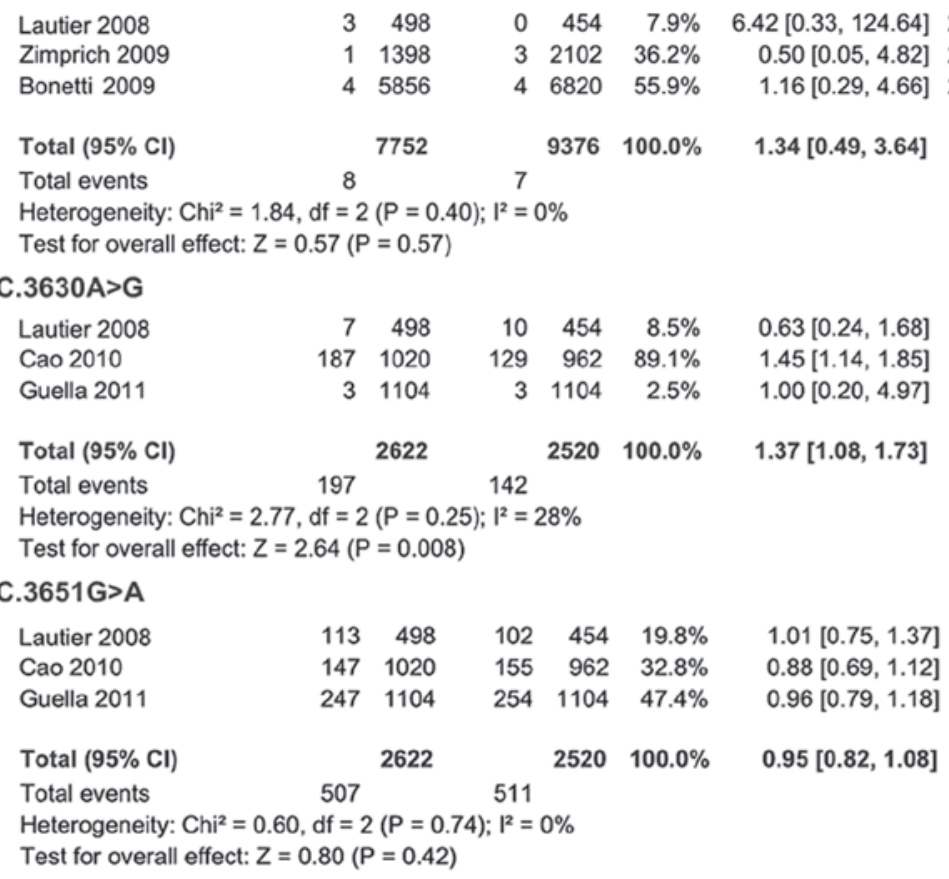
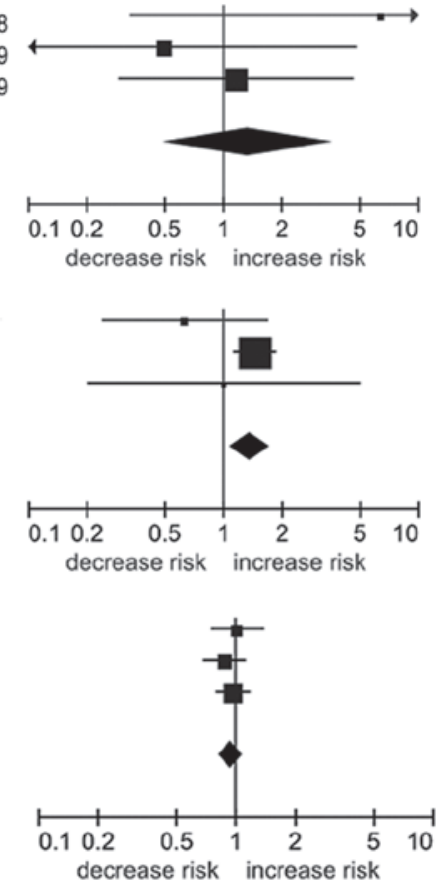

Figure 2. Forest plots of the GIGYF2 polymorphisms with Parkinson's disease. GIGYF2, Grb10-interacting GYF protein-2; CI, confidence interval. 
Table II. Meta-analyses of the GIGYF2 polymorphisms with Parkinson's disease.

\begin{tabular}{lcccccrr}
\hline Genetic locus & Cases/controls & Genetic model & $\mathrm{S}$ & OR $(95 \%$ CI) & P-value & I $^{2} \%$ & Power \\
\hline GIGYF2 C. $1378 \mathrm{C}>\mathrm{A}$ & $2281 / 1815$ & Overall (C vs. A) & 6 & $1.14(0.97-1.34)$ & 0.110 & 0 & 0.634 \\
GIGYF2 C.167C $>$ A & $5519 / 6316$ & Overall (G vs. A) & 5 & $3.67(1.56-8.68)$ & $0.003^{\mathrm{a}}$ & 41 & 0.063 \\
GIGYF2 C.1554G $>$ A & $1611 / 1460$ & Overall (G vs. A) & 4 & $0.94(0.59-1.50)$ & 0.790 & 82 & 0.526 \\
GIGYF2 C.2940A $>$ G & $1611 / 1460$ & Overall (A vs. G) & 4 & $1.09(0.97-1.22)$ & 0.150 & 40 & 0.885 \\
GIGYF2 C. 1370 C $>$ A & $3876 / 4688$ & Overall (C vs. A) & 3 & $1.34(0.49-3.64)$ & 0.570 & 0 & 0.065 \\
GIGYF2 C.3630A $>$ G & $1311 / 1260$ & Overall (A vs. G) & 3 & $1.37(1.08-1.73)$ & $0.008^{\text {a }}$ & 28 & 0.347 \\
GIGYF2 C.3651G $>$ A & $1311 / 1260$ & Overall (G vs. A) & 3 & $0.95(0.82-1.08)$ & 0.420 & 0 & 0.769 \\
\hline
\end{tabular}

${ }^{\mathrm{a}} \mathrm{P} \leq$ 0.05. GIGYF2, Grb10-interacting GYF protein-2; S, amount of studies; OR, odds ratio; CI, confidence interval.
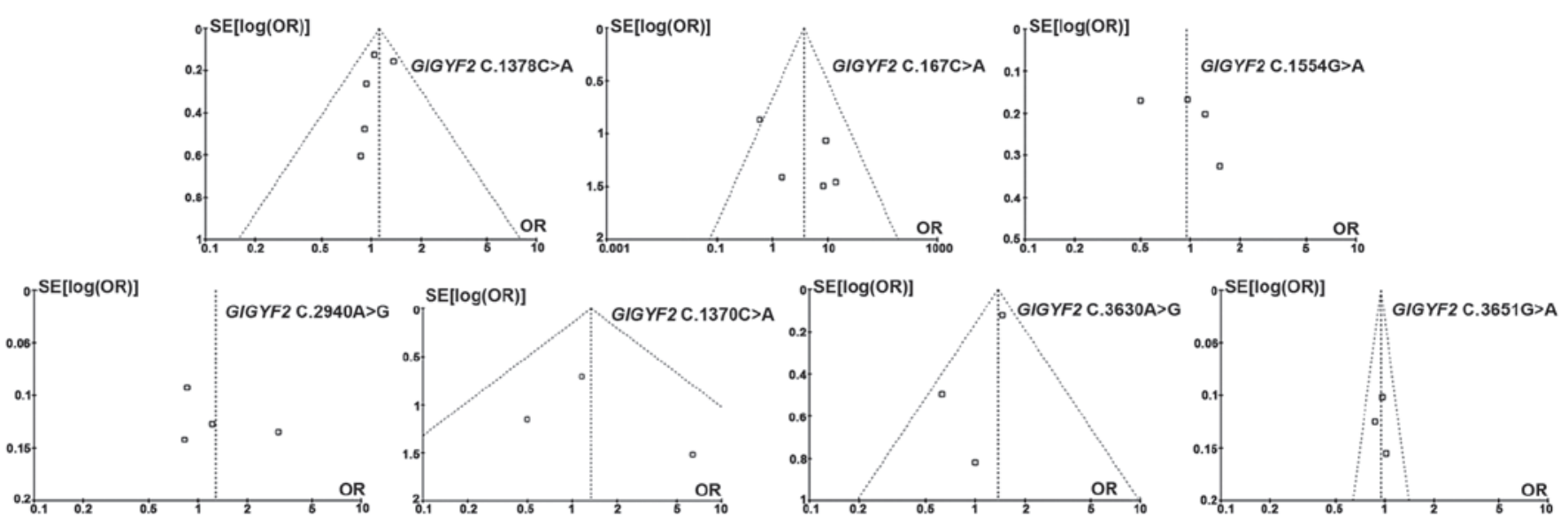

Figure 3. Funnel plots of the GIGYF2 polymorphisms with Parkinson's disease. GIGYF2, Grb10-interacting GYF protein-2; SE, standard error; OR, odds ratio.

were C.1378C $>$ A, C.1554G $>$ A, C.2940A $>$ G, C.1370C $>$ A and C.3651G $>$ A. The power was strong in the association studies of C.2940A $>\mathrm{G}$ and C.3651G $>$ A polymorphisms, but was relatively weak for the remaining three polymorphisms, which were C.1378C >A, C.1554G $>$ A and C.1370C $>$ A. A significant difference was found between ethnicities for the C.1378C $>$ A polymorphism (Fst=0.192), although there was minimal heterogeneity according to the meta-analysis of this polymorphism.

Several limitations of the present meta-analysis should be taken with caution. Firstly, only nine studies were included in the meta-analysis. The power values of the meta-analyses were low due to the MAF of certain polymorphisms. Secondly, PD is a complex and growing disease with a different physiological status existing in the PD cases. As the pathogenesis of familial and sporadic PD are not identical (55), family history as an independent risk factor for PD (56) should be emphasized in PD association studies. There were at least 1,818 sporadic and 861 familial PD patients involved in the present meta-analysis. Notably, two studies did not provide the information $(41,42)$. A previous study strongly supported that $G I G Y F 2$ was a causal factor of PD in the familial study (40). However, other studies showed a lack of association in sporadic PD studies $(33,35,54)$. Subgroup analysis by the PD family history is required to establish the role of genetic factors in the pathogenesis of PD. Thirdly, only seven polymorphisms of $G I G Y F 2$ were investigated, which may not fully reflect the function of GIGYF2 in PD. There are 9571 variants in the GIGYF2 according to the NCBI dbSNP database (http://www.ncbi.nlm.nih.gov/snp/?term=GIGYF2). Certain other variants, including C.684T $>A, C .1219 \mathrm{~A}>\mathrm{G}$ and C.3583C $>\mathrm{T}$, have been reported to be significantly associated with PD (37). In the present meta-analysis, those variants were not included due to a lack of relative information.

In conclusion, the present study found that the GIGYF2 C.3630A $>\mathrm{G}$ and $\mathrm{C} .167 \mathrm{G}>\mathrm{A}$ polymorphisms were associated with PD. Future investigations of other ethnic populations are required to establish the contribution of GIGYF2 to the risk of PD.

\section{Acknowledgements}

The present study was supported by the grants from the National Natural Science Foundation of China (grant nos. 31100919 and 81371469), Natural Science Foundation of Zhejiang Province (grant no. LR13H020003), K.C. Wong Magna Fund in Ningbo University and the Program for Professor of Special Appointment (Eastern Scholar) at Shanghai Institutions of Higher Learning (to Miss Mingqing Xu) and the Key Basic Research Foundation of Science and Technology Commission of Shanghai Municipality (grant no. 13JC1403700) (to Miss Mingqing Xu). 


\section{References}

1. Van Den Eeden SK, Tanner CM, Bernstein AL, et al: Incidence of Parkinson's disease: variation by age, gender, and race/ethnicity. Am J Epidemiol 157: 1015-1022, 2003.

2. Elbaz A, Bower JH, Maraganore DM, et al: Risk tables for parkinsonism and Parkinson's disease. J Clin Epidemiol 55: 25-31, 2002

3. Dauer W and Przedborski S: Parkinson's disease: mechanisms and models. Neuron 39: 889-909, 2003.

4. Mylius V, Engau I, Teepker M, et al: Pain sensitivity and descending inhibition of pain in Parkinson's disease. J Neurol Neurosurg Psychiatry 80: 24-28, 2009.

5. Grachev ID: Dopamine transporter imaging with [123I]FP-CIT (DaTSCAN) in Parkinson's disease with depressive symptoms: a biological marker for causal relationships? J Neurol Neurosurg Psychiatry 85: 130-131, 2014.

6. Blonder LX, Slevin JT, Kryscio RJ, et al: Dopaminergic modulation of memory and affective processing in Parkinson depression. Psychiatry Res 210: 146-149, 2013.

7. Aarsland D, Zaccai J and Brayne C: A systematic review of prevalence studies of dementia in Parkinson's disease. Mov Disord 20: 1255-1263, 2005.

8. Gan EC, Lau DP and Cheah KL: Stridor in Parkinson's disease: a case of 'dry drowning'? J Laryngol Otol 124: 668-673, 2010.

9. Klebe S, Golmard JL, Nalls MA, et al; French Parkinson's Disease Genetics Study Group; International Parkinson's Disease Genomics Consortium (IPDGC): The Val158Met COMT polymorphism is a modifier of the age at onset in Parkinson's disease with a sexual dimorphism. J Neurol Neurosurg Psychiatry 84 666-673, 2013.

10. Rode J, Bentley A and Parkinson C: Paraganglial cells of urinary bladder and prostate: potential diagnostic problem. J Clin Pathol 43: 13-16, 1990.

11. Najafi MR, Chitsaz A, Askarian Z and Najafi MA: Quality of sleep in patients with Parkinson's disease. Int J Prev Med 4 (Suppl 2): S229-S233, 2013.

12. Olanow CW and Tatton WG: Etiology and pathogenesis of Parkinson's disease. Annu Rev Neurosci 22: 123-144, 1999.

13. Wirdefeldt K, Adami HO, Cole P, Trichopoulos D and Mandel J: Epidemiology and etiology of Parkinson's disease: a review of the evidence. Eur J Epidemiol 26 (Suppl 1): S1-S58, 2011.

14. Vaglini F, Viaggi C, Piro V, et al: Acetaldehyde and parkinsonism: role of CYP450 2E1. Front Behav Neurosci 7: 71, 2013.

15. Tanner CM, Ottman R, Goldman SM, et al: Parkinson disease in twins: an etiologic study. JAMA 281: 341-346, 1999.

16. Alonso ME, Otero E, D'Regules R and Figueroa HH: Parkinson's disease: a genetic study. Can J Neurol Sci 13: 248-251, 1986.

17. Pankratz N, Nichols WC, Uniacke SK, et al: Genome-wide linkage analysis and evidence of gene-by-gene interactions in a sample of 362 multiplex Parkinson disease families. Hum Mol Genet 12: 2599-2608, 2003.

18. Dai D, Wang Y, Wang L, et al: Polymorphisms of DRD2 and DRD3 genes and Parkinson's disease: A meta-analysis. Biomed Rep 2: 275-281, 2014

19. Corti O, Lesage S and Brice A: What genetics tells us about the causes and mechanisms of Parkinson's disease. Physiol Rev 91: 1161-1218, 2011.

20. Singleton AB, Farrer MJ and Bonifati V: The genetics of Parkinson's disease: progress and therapeutic implications. Mov Disord 28: 14-23, 2013.

21. Cleary SF and Marciano-Cabral F: Soluble amoebicidal factors mediate cytolysis of Naegleria fowleri by activated macrophages Cell Immunol 101: 62-71, 1986.

22. Morrione A: Grb10 adapter protein as regulator of insulin-like growth factor receptor signaling. J Cell Physiol 197: 307-311, 2003.

23. Dufresne AM and Smith RJ: The adapter protein GRB10 is an endogenous negative regulator of insulin-like growth factor signaling. Endocrinology 146: 4399-4409, 2005.

24. Russo VC, Gluckman PD, Feldman EL and Werther GA: The insulin-like growth factor system and its pleiotropic functions in brain. Endocr Rev 26: 916-943, 2005.

25. Folli F, Ghidella S, Bonfanti L, Kahn CR and Merighi A: The early intracellular signaling pathway for the insulin/insulin-like growth factor receptor family in the mammalian central nervous system. Mol Neurobiol 13: 155-183, 1996.

26. Cardona-Gómez GP, Mendez P, DonCarlos LL, Azcoitia I and Garcia-Segura LM: Interactions of estrogens and insulin-like growth factor-I in the brain: implications for neuroprotection. Brain Res Brain Res Rev 37: 320-334, 2001.
27. Picillo M, Erro R, Santangelo G, et al: Insulin-like growth factor-1 and progression of motor symptoms in early, drug-naïve Parkinson's disease. J Neurol 260: 1724-1730, 2013.

28. Numao A, Suzuki K, Miyamoto M, Miyamoto T and Hirata K: Clinical correlates of serum insulin-like growth factor- 1 in patients with Parkinson's disease, multiple system atrophy and progressive supranuclear palsy. Parkinsonism Relat Disord 20: 212-216, 2014

29. Godau J, Knauel K, Weber K, et al: Serum insulinlike growth factor 1 as possible marker for risk and early diagnosis of Parkinson disease. Arch Neurol 68: 925-931, 2011.

30. Wang L, Guo JF, Zhang WW, et al: Follow-up study of variants of the GIGYF2 gene in Chinese patients with Parkinson's disease. J Clin Neurosci 18: 1699-1701, 2011.

31. Dos Santos AV, Pestana CP, Diniz KR, et al: Mutational analysis of GIGYF2, ATP13A2 and GBA genes in Brazilian patients with early-onset Parkinson's disease. Neurosci Lett 485: 121-124, 2010.

32. Wang L, Guo JF, Zhang WW, et al: Novel GIGYF2 gene variants in patients with Parkinson's disease in Chinese population. Neurosci Lett 473: 131-135, 2010.

33. Guo Y, Jankovic J, Zhu S, et al: GIGYF2 Asn56Ser and Asn457Thr mutations in Parkinson disease patients. Neurosci Lett 454: 209-211, 2009.

34. Li L, Funayama M, Tomiyama H, et al: No evidence for pathogenic role of GIGYF2 mutation in Parkinson disease in Japanese patients. Neurosci Lett 479: 245-248, 2010.

35. Cao L, Zhang T, Zheng L, et al: The GIGYF2 variants are not associated with Parkinson's disease in the mainland Chinese population. Parkinsonism Relat Disord 16: 294-297, 2010.

36. Tan EK, Lin CH, Tai CH, et al: Non-synonymous GIGYF2 variants in Parkinson's disease from two Asian populations. Hum Genet 126: 425-430, 2009.

37. Nichols WC, Kissell DK, Pankratz N, et al; Parkinson Study Group-PROGENI Investigators: Variation in GIGYF2 is not associated with Parkinson disease. Neurology 72: 1886-1892, 2009.

38. Zimprich A, Schulte C, Reinthaler E, et al: PARK11 gene (GIGYF2) variants Asn56Ser and Asn457Thr are not pathogenic for Parkinson's disease. Parkinsonism Relat Disord 15: 532-534, 2009.

39. Bras J, Simón-Sánchez J, Federoff M, et al: Lack of replication of association between GIGYF2 variants and Parkinson disease. Hum Mol Genet 18: 341-346, 2009.

40. Lautier C, Goldwurm S, Dürr A, et al: Mutations in the GIGYF2 (TNRC15) gene at the PARK11 locus in familial Parkinson disease. Am J Hum Genet 82: 822-833, 2008.

41. Bonetti M, Ferraris A, Petracca M, Bentivoglio AR, Dallapiccola B and Valente EM: GIGYF2 variants are not associated with Parkinson's disease in Italy. Mov Disord 24: 1867-1869, 2009.

42. Vilariño-Güell C, Ross OA, Soto AI, et al: Reported mutations in GIGYF2 are not a common cause of Parkinson's disease. Mov Disord 24: 619-620, 2009.

43. Meeus B, Nuytemans K, Crosiers D, et al: GIGYF2 has no major role in Parkinson genetic etiology in a Belgian population. Neurobiology Aging 32: 308-312, 2011.

44. Yu X, Huang Y, Li C, Yang H, Lu C and Duan S: Positive association between lymphotoxin-alpha variation rs909253 and cancer risk: a meta-analysis based on 36 case-control studies. Tumour Biol 35: 1973-1983, 2014.

45. Huang Y, Yu X, Wang L, et al: Four genetic polymorphisms of lymphotoxin-alpha gene and cancer risk: a systematic review and meta-analysis. PLoS One 8: e82519, 2013.

46. Tang L, Wang L, Liao Q, et al: Genetic associations with diabetes: meta-analyses of 10 candidate polymorphisms. PLoS One 8: e70301, 2013.

47. Xu X, Wang Y, Wang L, et al: Meta-analyses of 8 polymorphisms associated with the risk of the Alzheimer's disease. PLoS One 8: e73129, 2013

48. Excoffier L, Laval G and Schneider S: Arlequin (version 3.0): an integrated software package for population genetics data analysis. Evol Bioinform Online 1: 47-50, 2007.

49. Coory MD: Comment on: Heterogeneity in meta-analysis should be expected and appropriately quantified. Int J Epidemiol 39: 932-933, 2010

50. Kawalec P, Mikrut A, Wísniewska N and Pilc A: The effectiveness of tofacitinib, a novel Janus kinase inhibitor, in the treatment of rheumatoid arthritis: a systematic review and meta-analysis. Clin Rheumatol 32: 1415-1424, 2013. 
51. Giovannone B, Lee E, Laviola L, Giorgino F, Cleveland KA and Smith RJ: Two novel proteins that are linked to insulin-like growth factor (IGF-I) receptors by the Grb10 adapter and modulate IGF-I signaling. J Biol Chem 278: 31564-31573, 2003.

52. Laviola L, Giorgino F, Chow JC, et al: The adapter protein Grb10 associates preferentially with the insulin receptor as compared with the IGF-I receptor in mouse fibroblasts. J Clin Invest 99: 830-837, 1997.

53. Mori K, Giovannone B and Smith RJ: Distinct Grb10 domain requirements for effects on glucose uptake and insulin signaling. Mol Cell Endocrinol 230: 39-50, 2005.
54. Guella I, Pistocchi A, Asselta R, et al: Mutational screening and zebrafish functional analysis of GIGYF2 as a Parkinson-disease gene. Neurobiol Aging 32: 1994-2005, 2011.

55. Gasser T: Genetics of Parkinson's disease. J Neurol 248: 833-840, 2001.

56. Sellbach AN, Boyle RS, Silburn PA and Mellick GD: Parkinson's disease and family history. Parkinsonism Relat Disord 12: 399-409, 2006 